\title{
EARLY QUATERNARY HISTORY OF THE GENUS ARCHIDISKODON (PROBOSCIDEA, ELEPHANTIDAE) IN WESTERN SIBERIA: TO THE QUESTION OF INTERMEDIATE LINKS IN MAMMOTH LINEAGE
}

\author{
I.V. Foronova \\ V.S. Sobolev Institute of Geology and Mineralogy, Siberian Branch of Russian Academy of Science, Pr. Akad. Koptyuga 3, \\ 630090 Novosibirsk, Russia; e-mail: foronova@igm.nsc.ru
}

\begin{abstract}
The paper is concerned with the early representatives of the Archidiskodon-Mammuthus lineage from the sediments of Lower Pleistocene of the South of Western Siberia (Kuznetsk Basin). Several forms were being described within the genus Archidiskodon (A. meridionalis, A. m. tamanensis, A. m. voigtstedtensis, A. aff. wüsti) which represent consecutive steps of progressive development of the lineage on the early stage of its evolution. Morphometric features of molars (M3) have been studied using the author's original method designed for this group, which allowed specifying systematic attribution of the taxa under study and their position in the structure of the mammoth lineage. It was demonstrated that the form previously distinguished as Wüst's elephant and later attributed to the species M. trogontherii significantly differs from the latter in frequency and length of the plates. This form also stands out well statistically and is regarded as a separate and the latest taxon among the archidiskodon group of elephants. A. wö̈sti occupies a distinct position of an intermediate form (a 'bridge' as $\mathrm{H}$. Pohlig put it) between the genera Archidiskodon and Mammuthus in the structure of the mammoth lineage. Thus, the multi-dimensional diagrams used in our method permit to take a step close to revealing of so-called intermediate links in the mammoth lineage. Direction of phyletic development and some adaptations of the group in the second half of Early Pleistocene are also discussed. Account is also given to the accompanying fauna and the existence period of these species on the territory under study.
\end{abstract}

Key words: Archidiskodon, biostratigraphy, Early Pleistocene, Kuznetsk Basin, lineage, molars, Western Siberia

\section{РАННЕЧЕТВЕРТИЧНАЯ ИСТОРИЯ РОДА ARCHIDISKODON (PROBOSCIDEA, ELEРНАNTIDAE) В ЗАПАДНОЙ СИБИРИ: К ВОПРОСУ О ПРОМЕЖУТОЧНЫХ ЗВЕНЬЯХ В ФИЛЕТИЧЕСКОЙ МАМОНТОВОЙ ЛИНИИ}

\section{И.В. Форонова}

Институт геологии и минералогии им. В.С. Соболева, Сибирское Отделение Российской Академии наук, пр. Коптюга 3, 630090 Новосибирск, Россия; e-mail: foronova@igm.nsc.ru

\begin{abstract}
РЕЗЮМЕ
Статья посвящена ранним представителям линии Archidiskodon-Mammuthus из отложений нижнего плейстоцена юга Западной Сибири (Кузнецкая котловина). В пределах рода Archidiskodon описаны формы (A. meridionalis, A. m. tamanensis, A. m. voigtstedtensis, $A$. aff. wüsti), представляющие собой последовательные стадии прогрессивного преобразования линии на раннем этапе ее развития. Морфометрические данные коренных зубов (М3) изучены с помощью авторского метода исследования группы, что позволило уточнить систематическую принадлежность рассматриваемых таксонов и их положение в структуре филетической мамонтовой линии. Показано, что форма, выделявшаяся ранее под названием «слон Вюста», но впоследствии отнесенная к виду $M$. trogontherii, значимо отличается от последнего по частоте и длине пластин. Она также
\end{abstract}


хорошо выделяется статистически, и рассматривается, как самостоятельный и самый поздний таксон в составе архидискодонтной группы слонов. В структуре филетической мамонтовой линии $A$. wüsti занимает четкую позицию промежуточной формы (своеобразного моста, по словам Г. Полига) между родами Archidiskodon и Mammuthus. Таким образом, с помощью многомерных диаграмм используемого авторского метода стало возможным приблизиться к выявлению так называемых промежуточных звеньев в мамонтовой линии. Обсуждаются также направление филетического развития и некоторые адаптации группы во второй половине раннего плейстоцена. Приводятся сведения о сопутствующей фауне и времени существования описанных видов на рассматриваемой территории.

Ключевые слова: Archidiskodon, биостратиграфия, ранний плейстоцен, Кузнецкая котловина, филетическая линия, моляры, Западная Сибирь

\section{INTRODUCTION}

Elephants, well-adapted to various climatic and landscape conditions and able of wide dispersal and invasions to new territories, were one of the most predominant (in the terminology of Darlington 1966) mammal groups of the Pleistocene. Still, fossils of representatives of the genus Archidiskodon that inhabited Northern Eurasia in the Early Pleistocene (about 2.6-0.8 Ma) occur mainly in Western Europe and European part of Russia, while findings in the Asian Russia are rather rare. Natural and climatic conditions (temperature regime, water availability, vegetation structure and other natural factors) even in the southmost regions of Siberia were quite different from the European environment in the Early Pleistocene. Thus, population density of early archidiskodons on the initial stages of their dispersal to new Eastern areas apparently was not significant. Elephants reached the highest adaptive radiation as a result of evolutional transformation at the end of the Early Pleistocene, on the stage of Mammuthus. Scarce occurrence of ancient elephants may be explained by possible absence of the deposits of relevant age in the sedimentary cover, which depends on sedimentation and denudation in geomorphological conditions of specific Siberian regions. Moreover, natural exposures of fossil-bearing formations of this age are very rare and hardly available for examination. Even more, unfavorable conditions of fossilization may have had adverse impact on the integrity of fossil material.

Individual findings of archidiskodon elephants on the South of Western Siberia were made in Pavlodar Irtysh Land and on the Priobskoye Plateau in the Altai Region (Vangengeim and Zazhigin 1965, 1972; Vislobokova 1973, 1974, 1996; Zudin et al. 1977). A molar of archaic elephant has been found on the right bank of the Irtysh River near the village Podpusk, in the deposits correlated with the Kochkov Suite. It was defined as a beginning of the form A. gromovi Garutt et Alexeeva, 1964 typical of the Podpusk-Lebyazhean / Khapry faunal complex (= Early Pleistocene, Middle Villafranchian of Western Europe). More advanced A. cf. meridionalis (Nesti, 1825) from the Alei River and Ust-Talovka village (Altai Region) is a part of Razdolean/Taman faunal complex (= Early Pleistocene, late Late Villafranchian - Early Galerian).

Author has been studying numerous extremely thick artificial sections in coal-mining quarries of the Kuznetsk Basin, thus having succeeded to collect vast paleontological material (Foronova 1982, 1990, 1999, 2001a, b, 2014a, b, etc.), but even in these very favorable conditions fossil remains of the early archidiskodon elephants were not abundant. Nevertheless, even this material on Early Quaternary elephants in Western Siberia fairly matches and completes the overall picture of Archidiskodon-Mammuthus lineage development on the initial stages of its development.

Abbreviations. IGM, Sobolev Institute of Geology and Mineralogy, Russian Academy of Sciences, Siberian Branch, Novosibirsk; IAET, Institute of Archaeology and Ethnography, Russian Academy of Sciences, Siberian Branch, Novosibirsk; ZIN, Zoological Institute, Russian Academy of Sciences, St. Petersburg, Russia; PIN, Borissiak Paleontological Institute, Russian Academy of Sciences, Moscow, Russia; GIN, Russian Academy of Sciences, Moscow, Russia; MGPI, the Moscow Geological Prospecting Institute, Moscow; ROMK, Rostov-on-Don Regional museum, Rostov-on-Don, Russia; AMZ, Azov historical, archeological and paleontological museum-reserve, Azov, Russia; SMZ, Stavropol state museum-reserve, Stavropol, Russia; PKM, Pyatigorsk regional museum, Pyatigorsk, Russia; FGGUB, Department of Geology and Paleontology of the University, Bucharest, Romania. 


\section{LOCALITIES AND BIOSTRATIGRAPHY}

The Kuznetsk Basin $\left(54^{\circ} 13^{\prime} \mathrm{N}, 86^{\circ} 20^{\prime} \mathrm{E}\right)$ is the largest sedimentary basin in the central part of Asia. It is a part of the Altai-Sayan folded zone forming the southern and southeastern borders of the west Siberian Plain (Fig. 1). Here, a thick sequence of Quaternary deposits accumulated above the Paleozoic bedrock throughout the Late Cenozoic. These deposits represent different combinations of several alternating stages (suites) of subaerial, deluvial-proluvial (Mokhovo, Sergeevo, Berezovo, Bachatsk, Elovka) and lacustrine-alluvial (Sagarlyk, Kedrovka, Chernigovo and Krasnobrodsk) sedimentation (Foronova 1982, 1999, 2001b; Zudin et al. 1982). Fossil mammal localities are situated in seven open coal-mining quarries in which exposures stretch for many tens of kilometers (Fig. 1). Artificial extraction of sediments creates favorable conditions for collecting stratified fossils, so numerous findings have been made in all rock units.
The earliest fauna (analogous to the Kizikhian/ Psekups complexes = Lower Eopleistocene or Early Pleistocene, early Late Villafranchian of Western Europe) is recorded in the upper, reverse magnetized, part of Mokhovo Suite, at the base of the Quaternary succession. A normally magnetized episode in its lower part was also recorded. The suite comprises redbrown, massive, very compact clays containing calcareous concretions and red-bed fossil soils (though lighter than the clays, apparently due to great amount of concretions). The fauna is represented by rootless voles (Allophaiomys, Prolagurus, Eolagurus), Archidiskodon meridionalis (Nesti, 1825), the very large Equus singularis Foronova, 1990 from simplicidens-stenonis group, Cervalces (Libralces) sp., Ursidae, Bovini and Ovibovini gen. indet. Thus, predominant reverse magnetization of the Mokhovo Suite and age-dating of its upper part by the fauna of Early Eopleistocene allows to correlate the base of this bone bed (with 1-2 normal magnetic episodes) with Olduvai Event.

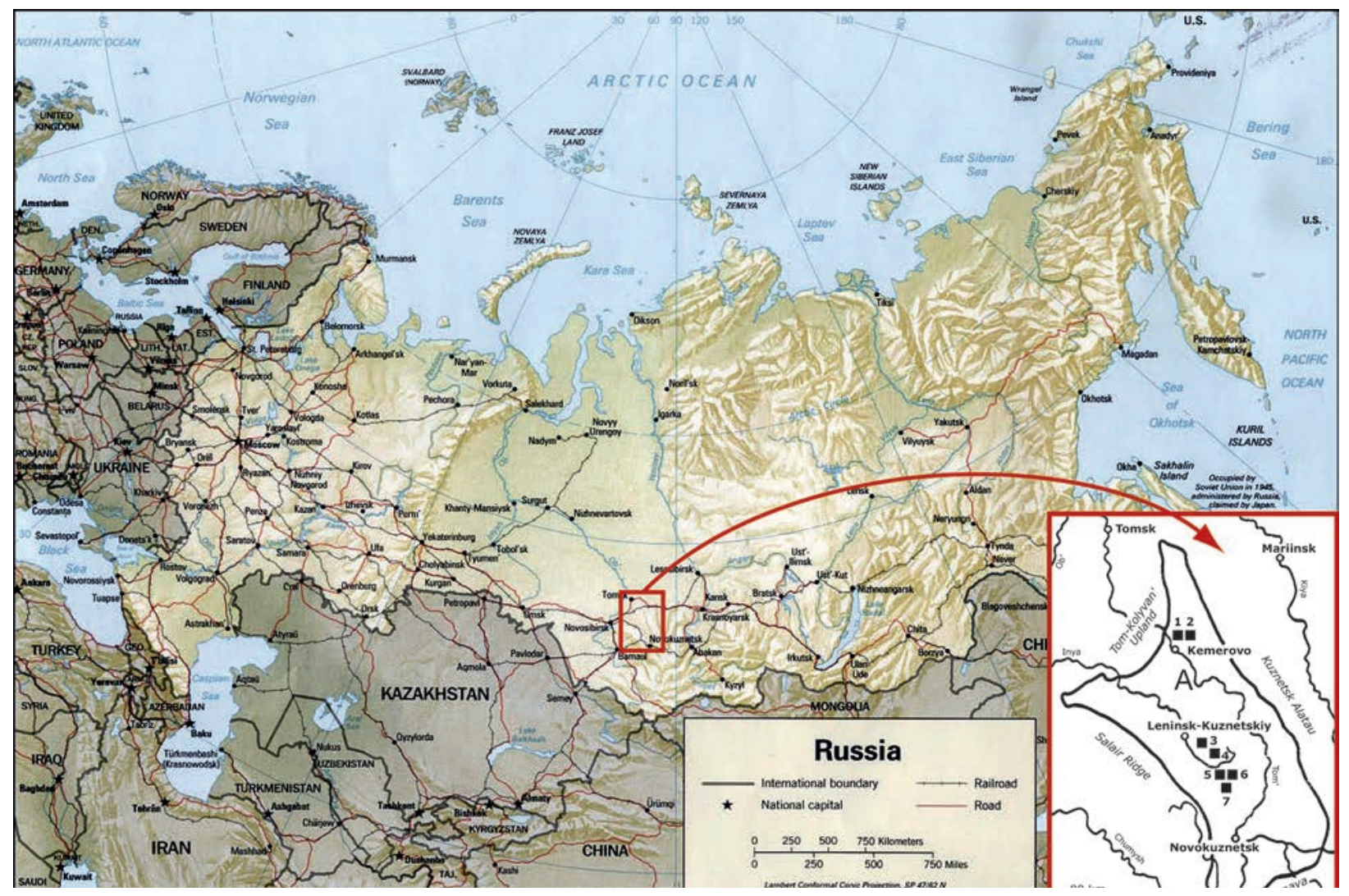

Fig. 1. Location of the Kuznetsk Basin. Coal-mining pits (fossil mammal localities): 1. Kedrovka; 2. Chernigovo; 3. Mokhovo; 4. Gramoteino; 5. Bachatsk; 6. Novosergeevo; 7. Krasnobrodsk. 
The fauna of the next stage (analogous to Razdolean/Tamanian complexes $=$ Upper Eopleistocene or Early Pleistocene, late Late Villafranchian - early Galerian of Western Europe) includes Prolagurus pannonicus Kormos, 1930, more advanced A. meridionalis tamanensis Dubrovo, 1964, Archidiskodon sp. (cf. A. tokunagai Mats.) from the Chinese, a large Panthera (Leo) fossilis (von Reichenau, 1906), E. cf. süssenbornensis Wüst, 1901, archaic caballoid horse (similar in tooth structure with E. simionescui Rad. et Sams., 1967), Cervalces aff. latifrons (Johnson, 1874) and large Bison sp. (ex. gr. priscus). The remains characterize the deposits of the Sagarlyk Suite - compact green-grey, stratified, clayey sands and clay silts. In the upper part of the Suite, the Jaramillo Subchron was recorded. Fossil seed assemblages present in these sediments contain an arctic-alpine flora (including Picea obovata, Abies, Pinaceae, Carex pauliflora and Ranunculus reptans). They imply humid and cold climatic conditions (like forest-tundra) and progressively decreasing temperatures. 'Cold' elements in the fauna and flora indicate complex climatic conditions of the second half of Early Pleistocene. In perspective, these elements could hold an opportunity of identifying warm and cold episodes within the Siberian Eopleistocene, which might correspond to those of European Russia, central and north-western Europe.

The concluding phase of this fauna was revealed in the lower part of overlying Sergeevo Suite. The latter represents a thick accumulation ( 5 to $30 \mathrm{~m}$ ) of compact light brown or pale-ocher sandy loams, containing several thick bright- or dark-brown fossil soils with plenty of mole holes. The fauna present in these sediments includes Pitymys, Microtus, Panthera sp., even more advanced $A$. meridionalis voigtstedtensis Dietrich, 1958, E. süssenbornensis, E. aff. simionescui, E. sanmeniensis Teilhard de Chardin et Piveteau, 1930, Cervini indet., and Bison ex gr. priscus Bojanus, 1827. Paleomagnetic section of Sergeevo Suite generally corresponds to reverse polarity of magnetic field. In European Russia this fauna is considered as Late Tamanian, analogous to final part of the Early Pleistocene - Early Galerian or transitional to Cromerian of Western Europe. In Western Europe, the faunas analogous to the Sagarlyk and Early Sergeevo are considered as transitional from Late Villafranchian to Galerian and their stratigraphical equivalents.

The conclusion of the Early Quaternary stage of fauna development in the Kuznetsk Basin is associ- ated with the most upper units of Sergeevo Suite containing fauna of very Early Pleistocene (Microtus sp., Panthera sp., Homotherium aff. ultimus Teilhard de Chardin, 1936, Archidiskodon aff. wüsti (M. Pavlowa, 1910), E. süssenbornensis, E. sanmeniensis, Bos sp. and Bison sp.), which may be correlated with transitional faunas between Late Tamanian and Early Tiraspolian of the European Russia and early Galerian/Cromerian faunas of Western Europe. Yet more progressive elements were recorded in the fauna of the next evolutionary level (the very beginning of Middle Pleistocene). They originate from the lower part (Krasnogorsk beds) of the Kedrovka Suite (lacustrine-alluvial bluish-grey clays with gravels, plant debris, hydromorphous fossil soils, containing a large number of bones). The Brunhes/Matuyama magnetic epoch boundary apparently occurs within the basal part of the Suite. Single sections of this part are reverse magnetized, while in the majority of the sections containing the fauna, normal polarity is found. This suite is characterized by: Gulo cf. schlosseri Kormos, 1914, first Mammuthus trogontherii (Pohlig, 1885), E. mosbachensis Reichenau, 1915, Rangifer sp., Bos sp. and large 'priscoid' Bison. This fauna is correlated with Early-Tiraspolian and Viatkian faunas in Russia and Cromerian faunas of Western Europe (Foronova 1982, 1990, 1999, 2001b, 2014b).

\section{MATERIAL AND METHODS}

Analysis is given to the series of upper and lower molars (M3) of archidiskodon elephants from the deposits of Mokhovo, Sagarlyk and Sergeevo suites, corresponding to the Lower Pleistocene (Eopleistocene of Russian Scheme). The material originates from Bachatsk, Mokhovo, Novosergeevo, Kedrovka open coal-mining quarries of the Kuznetsk Basin (Fig. 1) (collection of IGM).

Main morphometric features of molars (plate frequency on $100 \mathrm{~mm}$ stretch (PF), length of one plate (PL) and enamel thickness (E)) were studied. Values of these features are traditionally regarded as the major ones for defining of taxonomic position of mammoth lineage elephants. Still, it has long been demonstrated that straightforward traditional use of these values does not contribute to accurate identification and classification of forms due to wide variability and transgression (Garutt and Foronova 1976). Simple numerical representation of these values is also insufficiently informative. In order to 
solve these problems a new and uniform methodical (statistical) approach was required for the study of vast collected material.

Such a method has been elaborated and described in detail by Foronova and Zudin (1986, 1999, 2001) and discussed in subsequent publications (Foronova 2001a, b, 2007, 2014a, b). Nonetheless, in this paper it is necessary to describe it briefly, and provide some of previously published diagrams.

The method is based on plotting and analyzing multidimensional diagrams of values of the mentioned features (E, PF and PL) of several thousand molars (M3) belonging to representatives of the Archidiskodon-Mammuthus lineage from numerous Quaternary localities and archaeological sites in Northern Eurasia (Western and Eastern Europe, Western, Central, and Eastern Siberia) (Figs. 2, 3). Analysis was given to the collections of IGM, ZIN, PIN, GIN, MGPI, ROMK, AMZ, SMZ; of the Institut fur Quartärpaläontologie, Weimar, Germany; materials of many Universities and Regional Museums of Russia; Paleolithic sites of Russia: the Kurtak, Enisey River, Middle Siberia; the Kostenki group, Don River, Voronezh region; Khotylevo 1 and 2, Desna River, Briansk region; Dolni Vestonitse and Predmosti, in Czech Republic. Published materials were added to the analyses, as well. The teeth of contemporary Asian and African elephants from the collections ZIN were analyzed using measurements kindly offered by Dr. Vadim E. Garutt.

\section{Main principles of the method}

These characteristics are the key features defining the taxonomical position of mammoth species. The following indexes are calculated for each of last generation molars based on many measurements taken with calipers in at least two independent analyses.

1. Plate frequency $(\mathrm{PF})$ is the number of plates on $100 \mathrm{~mm}$ of crown. The index is an average based on measurements taken in the middle part of the lateral and medial surfaces of a crown.

2. Average length of a plate (PL). The term was suggested by Wüst (1901) and Söergel (1912), and the measurement includes an inter-plate space. It was included in analyses as an additional index. It was calculated as a mean of: (a) Quotient of division of crown length to total plate number; (b) Quotient of division of $100 \mathrm{~mm}$ to average plate frequency; (c) Mean of 6-10 measurements of three or five plates.
Measurements were taken on both sides of a crown and included inter-plate spaces.

3. Average enamel thickness (E) was calculated using an average from 10 to 20 measurements taken within the entire chewing surface. Thus, statistical reliability was achieved.

In the course of analysis of multidimensional diagrams in general, additional dental parameters were also used for comparison of individual clusters and evaluation of distribution pattern of molars. Width of a crown, total number of plates, hypsodonty index, angle of molar eruption, and angle of abrasive wear were analyzed using Kolmogorov-Smirnov's criterion (Miller and Kan 1965). Configuration of enamel 'loops' on the chewing surface and ratios of plate cement, dentine, and enamel in molars were also included in the analysis (Foronova and Zudin 1986). However, it has to be noted that length and height of a crown as well as number of plates (the factors depending on integrity of a molar and degree of attrition), despite their importance cannot be regarded as safe priority features for statistical analysis (as PF, PL and E on which the method is based). Other than that, a number of plates in a molar, though being a progressing evolutional feature, increases inconsistently from one form to another and so cannot have such systematic importance as assumed before. Maximum number of plates (30) was recorded in the "early" Mammuthus primigenius (Blumenbach, 1799) of beginning of the Late Pleistocene, not in the latest ones.

\section{Analysis of individual non-genetic variability}

The samples included into the analysis were selected based on their relative uniformity: different types of variability, except intraspecific variability, were excluded. Age variability of the teeth was eliminated given the analyses of only the last generation of molars (M3). Dentition asymmetry was analyzed through the example of European mammoths. Separate diagrams for lower, upper, right and left M3 are virtually undistinguishable: quantity, position and parameters of clusters remain almost the same (Foronova and Zudin, 1986, 1999, 2001; Foronova 2007). Variations of features from different stages of abrasive wear of a crown were excluded by enamel thickness measurement (along the entire chewing surface), described above. Pathological teeth occurred extremely rarely. However, their key features appeared to be similar to those of normal teeth. 
Geographical variability was excluded by plotting diagrams separately for Europe, Western and Eastern Siberia. These showed both similarity of the general structure and presence of an overwhelming majority of the elements, analogous in position and structure, on each diagram.

The method is highly informative and provides illustrative visual results. Not only it allows eliminating mentioned above difficulties, but it also provides crucially new information on the history of the group. Created multidimensional model demonstrates more complicated lineage structure than traditional gradual sequence emphasizing the canalizing evolutional selection in the group and discreteness of the natural selection. This utterly revolutionary fact has been demonstrated and justified in the very first papers of the authors of this method (Foronova and Zudin 1986, 1999, 2001).

Another extremely important result of the analyses was the revealed discreteness of the natural selection demonstrated by different molars' features, representing consequence of phenotype stabilization phases or most optimal dentition specialization levels characterizing certain stages of evolution of the mammoth lineage elephants. Clusters (we call them the "adaptive peaks") might represent separate taxonomical units on different taxonomical levels. Comparisons of diagrams constructed for the local mammoth populations from Europe, Eastern and Western Siberia reveal transcontinental expansion of the majority of the adaptive forms observed as clusters on the diagram (Figs. 2, 3). Some shifts in teeth parameters within analogous local populations may be an evidence of geographical clinal variation, which was caused by changing environment due to the global climatic changes. In addition to revealing the "adaptive peaks" in the axial zone of the diagram, we pioneered finding series of "peaks" within "thick-enamel" and "thin-enamel" teeth. These are oppositely oriented and clinally linked with the axial zone peaks. These new structural elements can be traced through the entire lineage beginning from the earliest archidiskodons, but most clearly in the mammoths' part of the diagram (within the genus Mammuthus) (Figs. 2, 3). Thin-enamel and thick-enamel forms differ morphometrically reflecting different functional applications. "Thin-enamel" forms are characterized by thin and slightly folded enamel, absence of extension in the middle part of plate (medial sinus), especially of mammoths from
Europe and Western Siberia, and a specific adaptive feature - narrow and widely spaced plates. Certain widening of a cement area between the plates in this case is caused by decreased length of a plate, which consists of enamel and dentine. Heavy wearing of soft cement of the teeth makes narrow plates with enamel edging stand out of the rest of the chewing surface. Such thin-enamel plates of teeth enhanced cutting and milling capabilities of mammoth dentition. This adaptive feature was undoubtedly effective for mammoths dieting on rough herbaceous vegetation. Different distribution ranges of the 'thin-enamel' and 'thick-enamel' forms of mammoths are also significant factor emphasizing different ecological specializations of these forms. Morphofunctional differences, the data on accompanying fauna and flora, different distribution ranges and some absolute dates allow correlating these forms with the periglacial and interglacial environments of the Quaternary.

Some of the discussed molars have been previously described, however, additional study with the help of the authors' method allowed specifying their systematic attribution and position of these forms in the structure of the lineage. Nevertheless, many unanswered questions remain, since description and classification of the archidiskodon group was extremely confused through the whole history of its study. Again, it is worth emphasizing that the fact that scientists lacked a uniform method and used different approaches to measuring molars has led to many inaccuracies, generalized diagnoses and often to totally incomparable results. All of these factors greatly impede analysis and comparison of the forms.

\section{SYSTEMATICS}

\section{Proboscidea Illiger, 1811}

Elephantidae Gray, 1821

Mammuthinae Simpson, 1945

Archidiskodon Pohlig, 1885

Archidiskodon meridionalis (Nesti, 1825)

(Figs. 2, 3, 4)

Material. Anterior fragment of the upper M3 dex, heavily worn and rounded, (IGM 3580), Mokhovo Suite, Novosergeevo Quarry. Upper M3 dex, moderately worn (IGM 7090), Mokhovo Suite, Bachatsk Quarry. 


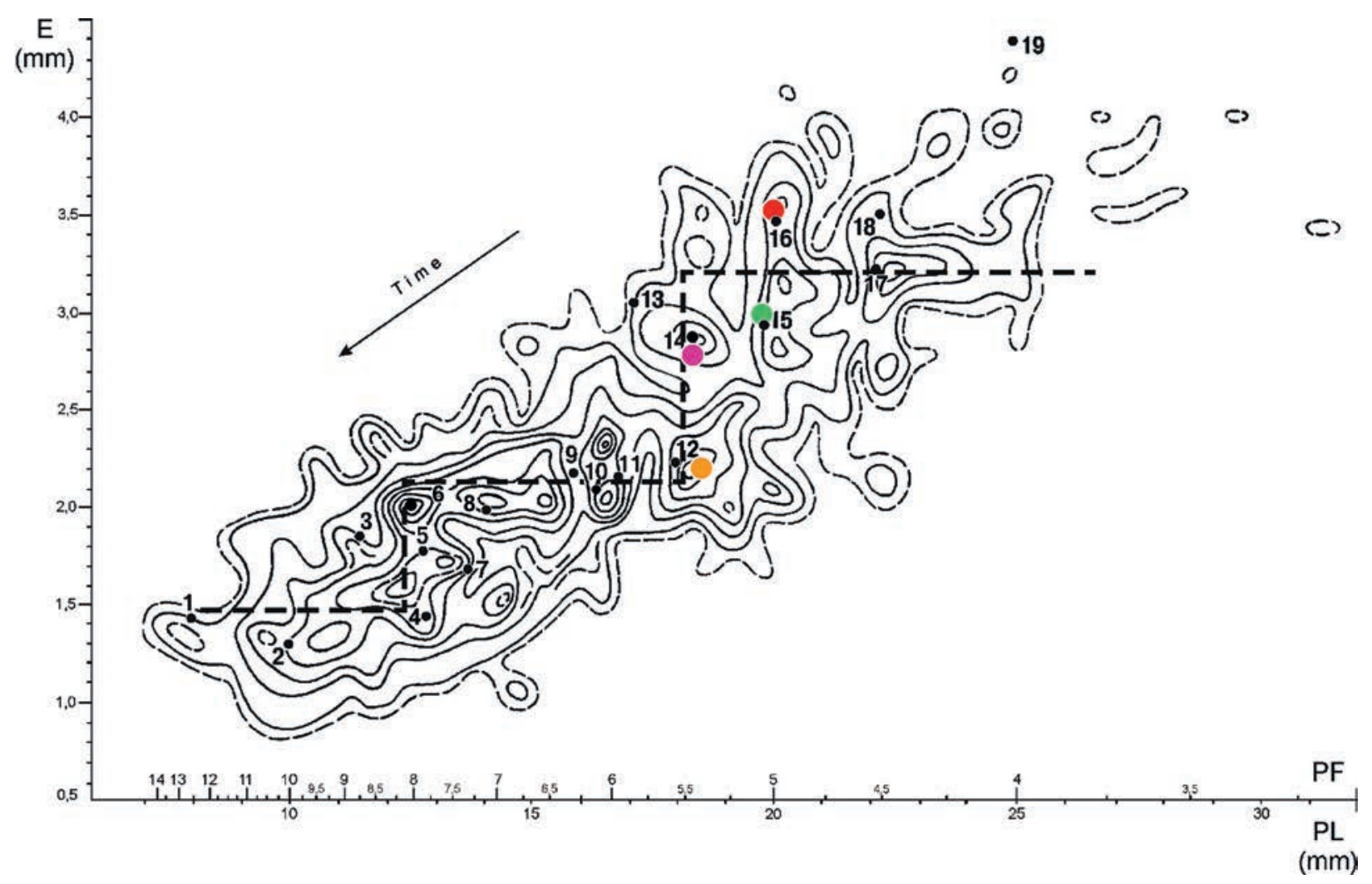

Fig. 2. Variability of the elephants of the mammoth lineage in Europe according to M3 parameters (by materials from Western and Eastern Europe) (after Foronova and Zudin 1999, with modifications). Legend: Coordinate axis: E - enamel thickness; PF - plate frequency on $100 \mathrm{~mm}$ stretch; PL - length of one plate. Continuous isolines of distribution density are drawn through 0.5 Uniform Density Units, punctuated isolines are drawn through 0.25 Units, outer isoline corresponds to 0.25 . Punctuated lines show assumed direction of lineage development due to selection pressure.

Dots are the coordinates of typical specimens of taxa distinguished in the lineage and some peculiar forms: 1. M. primigenius sibiricus; 2. M. primigenius primigenius, neotype; 3. M. primigenius jatzkovi, holotype; 4. M. primigenius fraasi, holotype; 5 . M. primigenius, early form, average parameter values; 6. M. primigenius (Chokurcha site); 7. M. primigenius, lectotype; 8. M. intermedius, holotype; 9 . M. trogontherii chosaricus, holotype; 10. M. trogontherii chosaricus, holotype (authors' measurements); 11. M. trogontherii trogontherii, lectotype; 12. M. trogontherii (Azov museum; authors' measurements) = A. wë̈sti; 13. A. meridionalis cromerensis, holotype; 14. A. m. voigtstedtensis, holotype; 15. A. m. tamanensis, holotype; 16. A. meridionalis, average parameter values (Psekups River, Northen Caucases); 17. A. m. meridionalis, holotype; 18. A. gromovi; 19. A. m. taribanensis.

Color dots stand for average values of parameters (PF, PL and E) of the elephant forms described on the basis of the material from South of Western Siberia (Kuznetsk Basin): red - A. meridionalis; green - A. m. tamanensis; lilac - A. m. voigtstedtensis; yellow - A. wüsti.

Geological age. Early Pleistocene, early Late Villafranchian.

Description and comparisons. The M3 fragment consists of three very thick plates. The tooth appears to consist of plates only, interlamellar spaces being virtually absent. Average antero-posterior length (PL) of a plate is $20.0 \mathrm{~mm}$. The enamel is thick, roughly folded and strongly projecting on the occlusal surface. Its thickness (E) averages $3.5 \mathrm{~mm}$. The specimen is only a fragment, so other dimensions are not provided. Though deeply worn, the tooth retains a pronounced attrition figure due to deep plate dis- section consisting of two rounded lateral ovals and a broad median sinus $(-\mathrm{o}-)$. The tooth in question differs from late $A$. meridionalis in the larger average plate length and enamel thickness as well as in the peculiar attrition figures. This characteristic feature can be traced almost down to the base of the crown, each plate being deeply dissected with vertical slits into three roughly equal parts. Special importance is attached to this feature which is considered to be more pronounced in the geologically most ancient forms. On the other hand, closeness of the plates which is not typical of archaic forms may be also explained by 


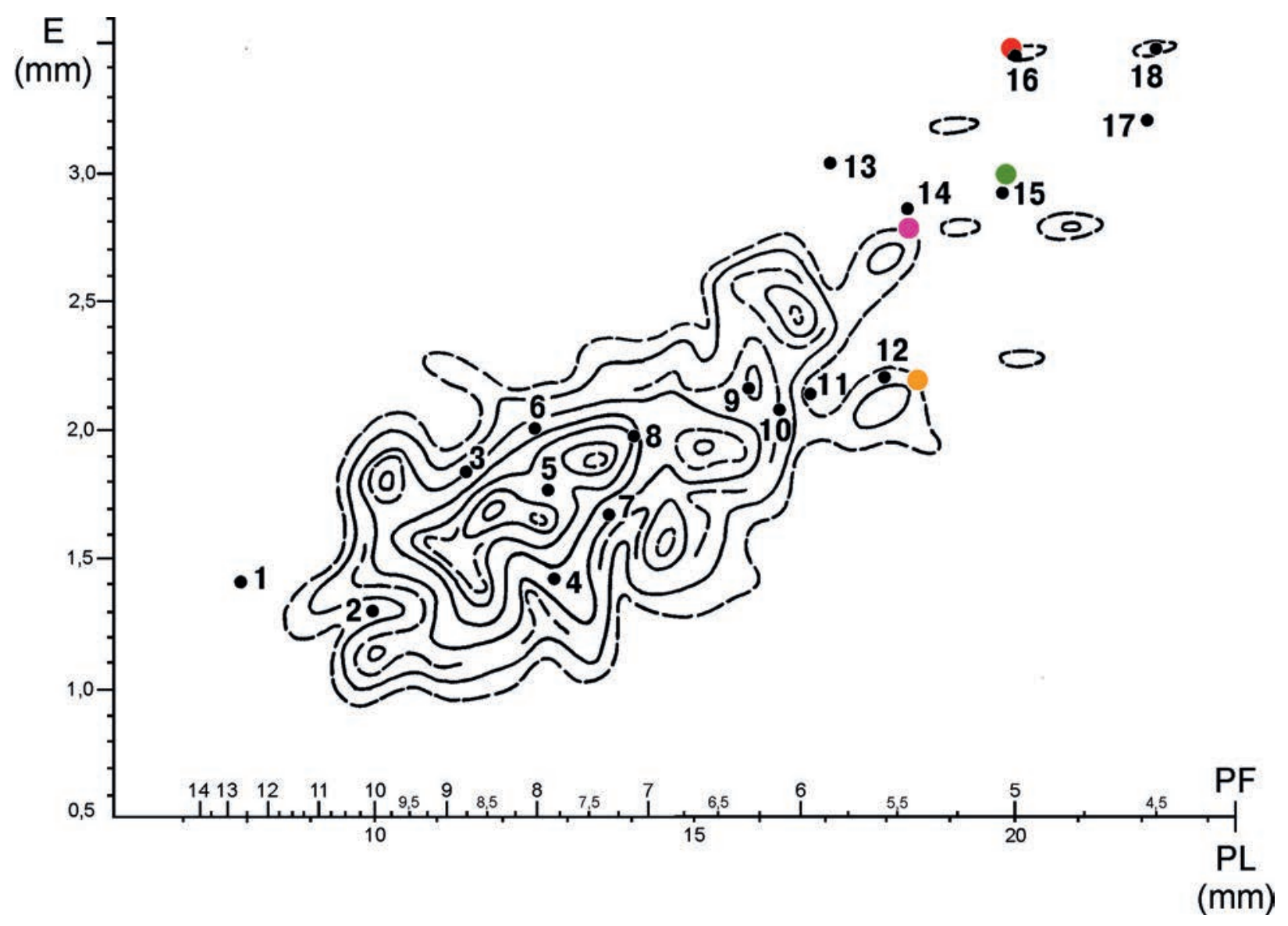

Fig. 3. Variability of the elephants of the mammoth lineage, after the material from Kuznetsk Basin (South of Western Siberia). See Fig. 2 for legend.

the attrition of the molar (almost to the base of the crown). In enamel thickness and the nature of subdivision of the plates and their frequency, the tooth does not differ from the $A$. gromovi teeth reported from Liventsovka and Khapry in the European Russia (Garutt and Alexeeva 1964; Alexeeva and Garutt 1965; Alexeeva 1977; Garutt and Bajgusheva 1981) and from Podpusk in southern West Siberia (Vislobokova 1974, 1996). The molar (IGM 7090) is large, it contains 12 plates, $1-2$ anterior plates are absent. Total number of plates did not exceed 14. Maximal crown width $116.0 \mathrm{~mm}, \mathrm{PF}: 5$, E: $3.5 \mathrm{~mm}$, it has large foldings. Two most worn plates are band-like and slightly widened in the middle.

The diagram (Fig. 2) demonstrates that the parameters (FL: 5, PL: $20.0 \mathrm{~mm}$ and E: $3.5 \mathrm{~mm}$ ) of both first and second molars from the Kuznetsk Basin absolutely correspond to the average values of these parameters of $A$. meridionalis (point 16) from
Psekups fauna localities of the Northern Caucasus: Georgievsk (collections of SMZ, and PKM), and Psekups (Vereshchagin 1959; Foronova and Zudin 1986, 1999; Foronova 2001a, b; Baygusheva and Titov 2012). However, Psekups molars correspond to another adaptive peak, which is more advanced in plate frequency and plate length than the one corresponding to the parameters of lectotype (Point 17) of A. meridionalis meridionalis (Maglio 1973; Dubrovo 1964).

The molar fragment (IGM, 3580) was initially defined as $A$. cf. gromovi. However, later with the help of our method (Foronova and Zudin 1986, 1999, etc.) and especially by means of informative diagrams it was clearly demonstrated, even at that time, that so-called Gromov's elephant (at least based on the parameters of last molars) cannot be distinguished as a separate taxon. In this regard, it is important to note that average PL and E values of Gromov's ele- 


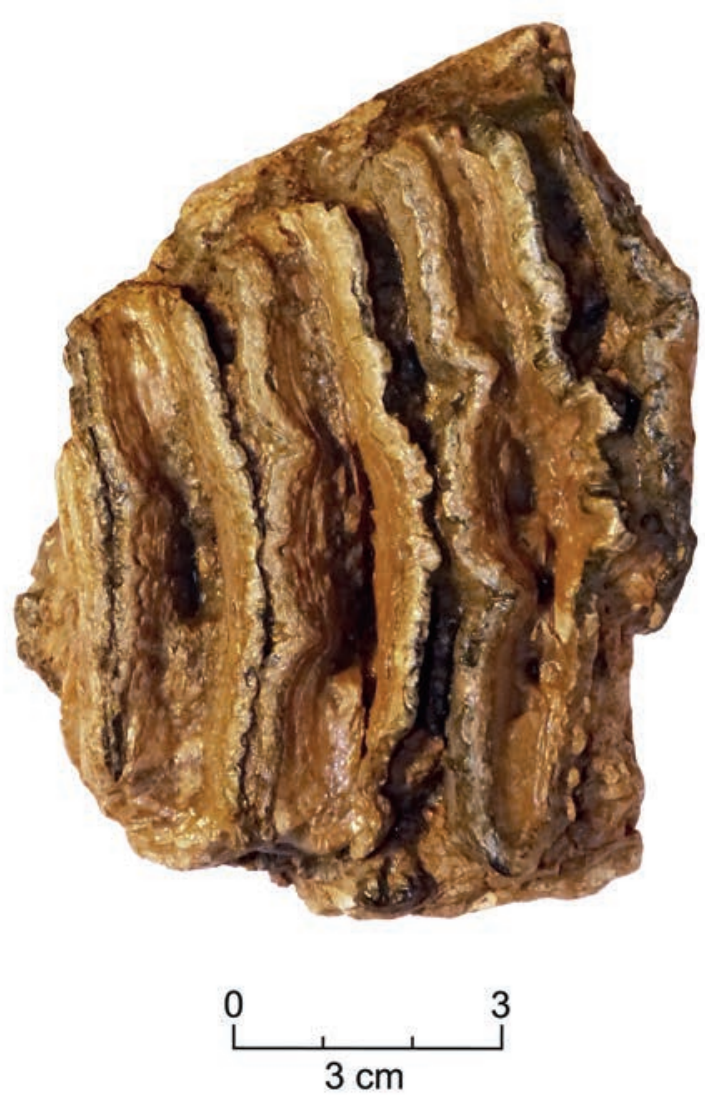

Fig. 4. Archidiskodon meridionalis (Nesti, 1825). Fragment of the upper M3 dex (IGM 3580), Mokhovo Suite, Novosergeevo Quarry.

phant (Fig. 2, Point 18) according to author's own measurements (Garutt and Foronova 1976) and the data of Alexeeva (1977) and Baygusheva and Titov (2012) are located within a well-pronounced adaptive peak - fairly substantial group of molars of the earliest "meridionaloid" elephants.

It has to be pointed out that the grouping-center of this adaptive peak coincides with the Point 17 lectotype of subspecies A. meridionalis. So, the diagram shows that M3 parameters of Gromov's Elephant are almost similar to those of the holotype of nominal subspecies $A$. meridionalis and only slightly exceed the latter in enamel thickness (possibly due to inaccuracy of measurements). It has to be noted that Dubrovo (1964) disclaimed the independence of $A$. gromovi and considered it as a part of $A$. meridionalis meridionalis. The fact that holotypes of $A$. gromovi (point 18) and A. m. meridionalis (point 17) combine into one adaptive peak on the diagram (Fig. 2) we re- gard as a good albeit untimely illustration (Foronova and Zudin 1999) of this I. A. Dubrovo's point of view by our method, and a confirmation of its efficiency. As for the elephants of this evolutional level from the Kuznetsk Basin, the provided data allow to attribute them only as exactly as belonging to the species A. meridionalis Nesti.

\section{Archidiskodon meridionalis tamanensis Dubrovo, 1964}

(Figs. 2, 3, 5, 6)

Material. Upper M3 sin (IGM 4096), about five anterior plates missing. Sagarlyk Suite, Mokhovo Quarry. Two upper M3 sin (IGM 5, 8), Sagarlyk Suite, Novosergeevo Quarry. Fragment of lower M3 sin (IGM 24), includes 8 plates, Sagarlyk Suite, Kedrovk Quarry.

Geological age. Early Pleistocene, late Late Villafranchian - Early Galerian.

Description and comparisons. Size of molar (IGM 4096) is large (width $105.0 \mathrm{~mm}$, height of unworn plate $175.0 \mathrm{~mm}$ ). Of the nine preserved plates, four are worn, PL: $19.0 \mathrm{~mm}$, E: $3.2 \mathrm{~mm}$, and roughly folded. The plates are clearly separated into three ovals. Dissection reaches the middle of the crown, being clearly distinctive in transverse section. A second section at $4 \mathrm{~cm}$ from the crown base reveals the plates losing the three section structure and the ovals merging into one, slightly broadened in the middle. The very dense arrangement of plates is characteristic of this tooth. The section through the middle of the crown shows interlamellar spaces to be present between the ends of plates only, while in basal section the spaces are virtually absent, the plates being tightly pressed one to another. This peculiar feature is common both to the tooth under discussion and to the above tooth of $A$. meridionalis (IGM 3580).

All features considered, the examined tooth undoubtedly belongs to the group of meridionaloid elephants, but substantial crown height, low interlamellar spaces, absence of deep division of the plates and middle meridionaloid attrition figure $(-\mathrm{o}-)$, especially in the basal part of the tooth make it different from typical form of $A$. meridionalis, according to Dubrovo 1964.

M3 (IGM 5) has 15 plates preserved, about four plates are broken away in the anterior part of the crown. Size large; the fragment is $256 \mathrm{~mm}$ long. The crown is considerably widened in the middle, 

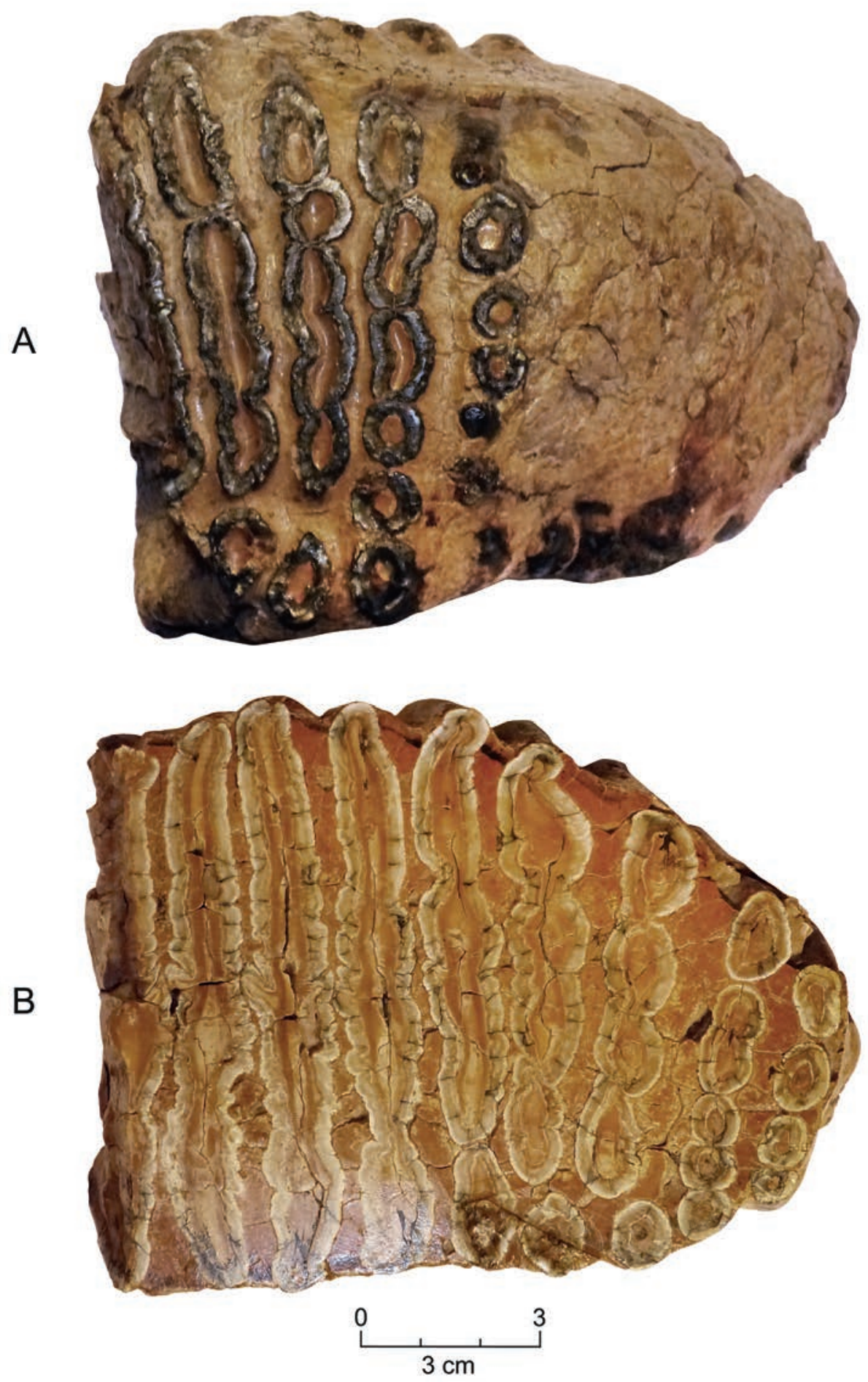

Fig. 5. Archidiskodon m. tamanensis Dubrovo, 1964. Upper M3 sin (IGM 4096), Sagarlyk Suite, Mokhovo Quarry. A - upper part of the crown; B - saw-cut in the middle part of crown. 


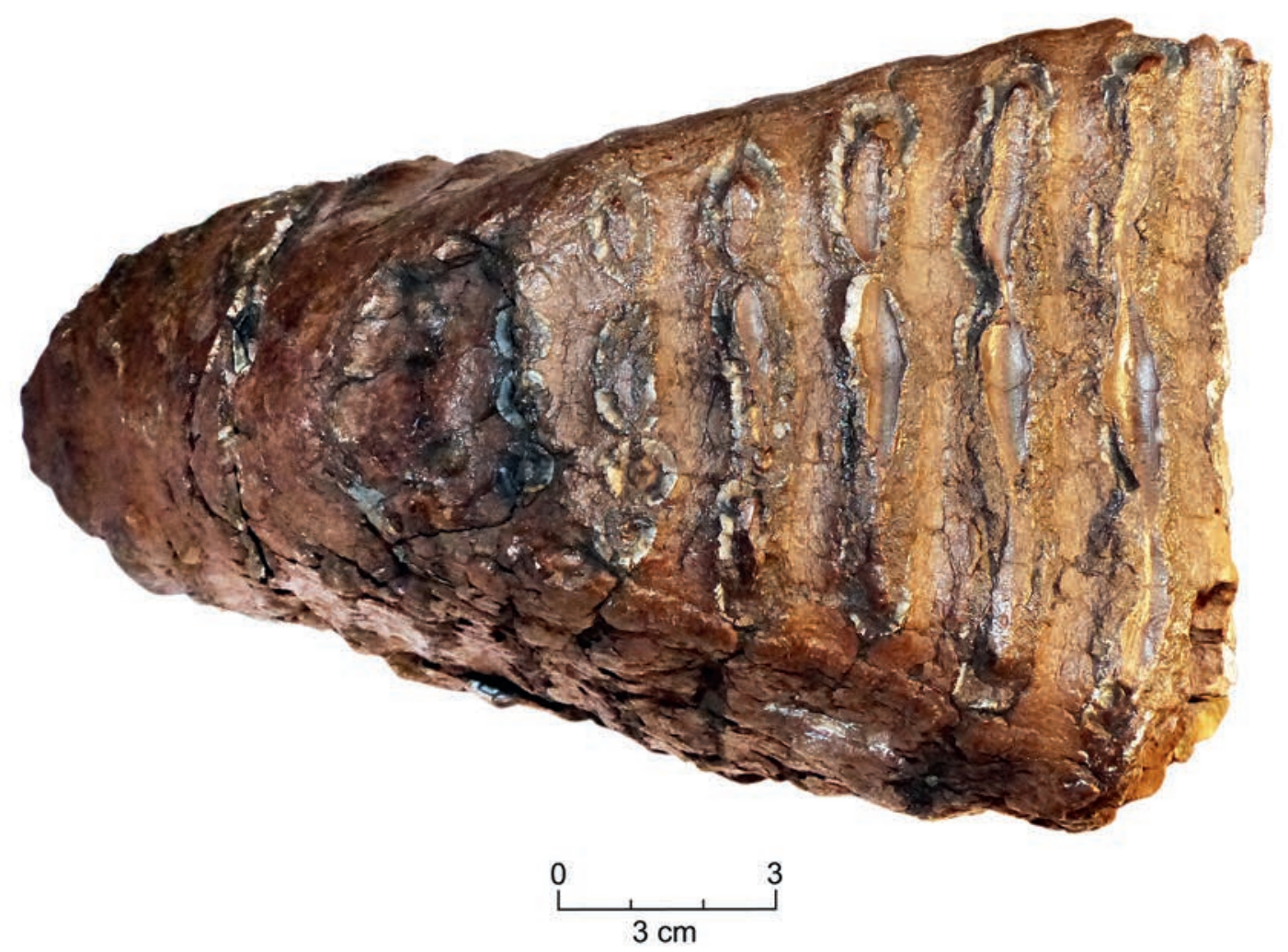

Fig. 6. Archidiskodon m. tamanensis Dubrovo, 1964. Upper M3 sin (IGM 5), Sagarlyk Suite, Novosergeevo Quarry.

narrowing uniformly posteriorly. The least unworn plate is $180 \mathrm{~mm}$ high. PL: $17.6 \mathrm{~mm}$; E: $2.7 \mathrm{~mm}$. In the early stage of wear they show a pronounced pattern of three equal ovals $(---)$. On the anterior plates, which are worn down to form complete loops, three oval patterns can still be observed on account of two waists separating the plate into three almost equal parts. In a section cut through the middle of the crown the mean of PL: $19.0 \mathrm{~mm}$, almost all plates show median broadening but at this level vertical dissection into three parts is almost unpronounced. Enamel thickness in section is $2.7-2.8 \mathrm{~mm}$. Fragment of (IGM 8) has a rather wide crown $(117 \mathrm{~mm})$. The height of the least worn plate is $150 \mathrm{~mm}$ PL: $21 \mathrm{~mm}$, E: $2.9 \mathrm{~mm}$. Attritional figures in the initial stage of wear consist of three ovals $(---)$. In the middle part of the crown (in cut section) the side and median ovals fuse to form a complete loop broadened in the middle. The measurements of (IGM 24) are omitted, because the crown was partially damaged and broken posteriorly. The plates are large and widely separated,
PL: $20.8 \mathrm{~mm}$, E: $2.8 \mathrm{~mm}$. Each plate shows a complete loop with pronounced median broadening.

Features of the provided molars show that on the account of middle length and frequency of the plates they do not go beyond the limits of $A$. meridionalis from Psekups (Fig. 2, Point 16), while in terms of enamel thickness they appear to be more progressive. Width and height of the crown are indicative of the same. This interesting fact requires explanation (see below). Averaged values of the parameters of these four molars from the Kuznetsk Basin (PL: $19.9 \mathrm{~mm}$, E: $3.0 \mathrm{~mm}$ ) are marked by green point in Figs. 2, 3 and clearly prove these molars to belong to its later subspecies A. m. tamanensis Dubrovo, 1964 - a characteristic representative of late Late Villafranchian early Galerian Taman Faunistic Complex.

This form is known from a number of the Eastern European localities on the coast of the Sea of Azov and specifically numerous findings from the stratotype site of Taman complex - Sinyaya Balka (Baygusheva and Titov 2008; Nikolskiy et al. 2014; Tesakov 2004, etc.). 
A similar absence of the mentioned features has also been reported for teeth resembling $A$. meridionalis from Ust - Talovka (Altai foothills) by Vislobokova (1973). Characteristics of paired lower M3 of this form: crown length: about $300 \mathrm{~mm}$; width: 116.0-117.0 mm; height: about 150.0-160.0 мм; plate number: 16; PL: $21.0 \mathrm{~mm}$, E: $2.7 \mathrm{~mm}$ (author's measurements). Still, the tooth described also differs from the Altai specimen in having shorter interlamellar spaces.

Parameters of the provided Siberian teeth show that on the account of middle length and frequency of the plates they do not go beyond the limits of $A$. meridionalis from Psekups (Northern Caucasus), while they appear to be more advanced in enamel thickness. Crown width and height are also indicative of their progressiveness.

Thus, in the end of Early Pleistocene in the Razdolean fauna of the South of Western Siberia (synchronous to Early Tamanian fauna of the European Russia) there was more advanced form of the Southern Elephant with the typical M3 features: thinner enamel, relatively narrow and significantly high crown. The width of a crown gradually changes, slightly decreasing from the archaic to the later forms, whereas the hypsodonty index increases 'leap-like' on the borders of the adaptive peak ensembles (Fig. 2). The first such leap coincides with the border between the ensembles, which include A.m. meridionalis and A.m.tamanensis.

It is important to stress that it has been long since scholars noted morphological inconsistency of elephant material from various localities of Northern Eurasia of Late Villafranchian - Early Galerian age. As for the Sinyaya Balka locality (South of Russia, Azov Sea region), there are different views on the specific structure of this locality and its faunal composition. Belyaeva (1925) refers to 2 forms: "Elephas" meridionalis and "E." trogontherii; Vereshchagin (1957) distinguished "E.” meridionalis, "E.” trogontherii, and "E." antiquus; Dubrovo (1963a) described the subspecies A. meridionalis tamanensis. According to the modern view (Baygusheva 2000; Baygusheva and Titov 2008, 2010, 2012), in the Sinyaya Balka sample there are morphologically similar teeth, which can be divided into 2 groups. The first group is reliably correlated with $A$. m. tamanensis. The taxonomic status of the second form is not yet defined. Similar situation is being discussed in Western Europe (Lister and Sher 2001; Lister et al. 2005; Lister and Stuart
2010). Authors report presence of remains of progressive "M." meridionalis and early $M$. trogontherii at the collection and assume bimodal characteristics of the teeth (quantity and frequency of the plates).

As for Western Siberia, the author have previously pointed out morphological inconsistency of elephant sample in the faunas of this geological age (from Sagarlyk and Sergeevo Suites of Kuznetsk Basin) (Foronova 1982, 1990, 2001b). Creation of the discussed method (Foronova and Zudin 1986, 1999, 2001, etc.) and its informative diagrams gives another look at the problem.

\section{Archidiskodon meridionalis voigtstedtensis Dietrich, 1958}

(Figs. 2, 3, 7)

Material. Two lower M3 sin (IGM 687, 3523), Sergeevo Suite and lower M3 sin (IGM 6), upper unit of Sagarlyk Suite, Novosergeevo Quarry. Two lower M3 dex (IGM 9271) and M3 sin (IGM 9272), upper units of Sagarlyk - lower part of Sergeevo Suite, Mokhovo Quarry. Two upper (paired) M3 sin (IGM 608) and M3 dex (IGM 609), lower part of Sergeevo Suite, Bachatsk Quarry.

Geological age. Final part of Early Pleistocene, Early Galerian.

Description, comparisons and remarks. M3 fragment (IGM 686) includes nine plates. Crown measurements are not listed because of heavy damage. Attrition figures are distinctive $(---)$, the median broadening being well-pronounced. PL: $18.6 \mathrm{~mm}$, E: $2.75 \mathrm{~mm}$. M3 (IGM 927) large, slightly attrited, width: $95.0 \mathrm{~mm}$, height: over $152.0 \mathrm{~mm}$, PF: 5.7, PL: $17.6 \mathrm{~mm}, \mathrm{E}: 2.8 \mathrm{~mm}$. M3 (IGM 9272) (sawcut), width: $95 \mathrm{~mm}$, height: $150 \mathrm{~mm}$, PL: $17.9 \mathrm{~mm}$; E: $2.8 \mathrm{~mm}$. M3 (IGM 3523 large, more than half - attrited, PL: $18.5 \mathrm{~mm}, \mathrm{E}: 2.8 \mathrm{~mm}$. M3 (IGM 6) large, width: $100.0 \mathrm{~mm}$, height: $185.0 \mathrm{~mm}$, PF: 5.5; Pl: $18.5 \mathrm{~mm}$; E: $2.82 \mathrm{~mm}$. Paired molars (IGM 608, 609): PL: 17.5 and $18.0 \mathrm{~mm}$; E: 2.75, $2.7 \mathrm{~mm}$.

Parameters of the described molars are rather compactly stationed in the area of well-pronounced adaptive peak, which is situated, relatively to $A . m$. tamanensis, in more progressive part of the diagrams (Figs. 2,3) in terms of frequency and length of the plates but retains the $\mathrm{E}$ values in previous limits (similar to A. m. tamanensis). Parameters of the holotype $A$. m. voigtstedtensis Dietrich, 1958 (Fig. 2, Point 14) from the main layer of Voigtstedt in 


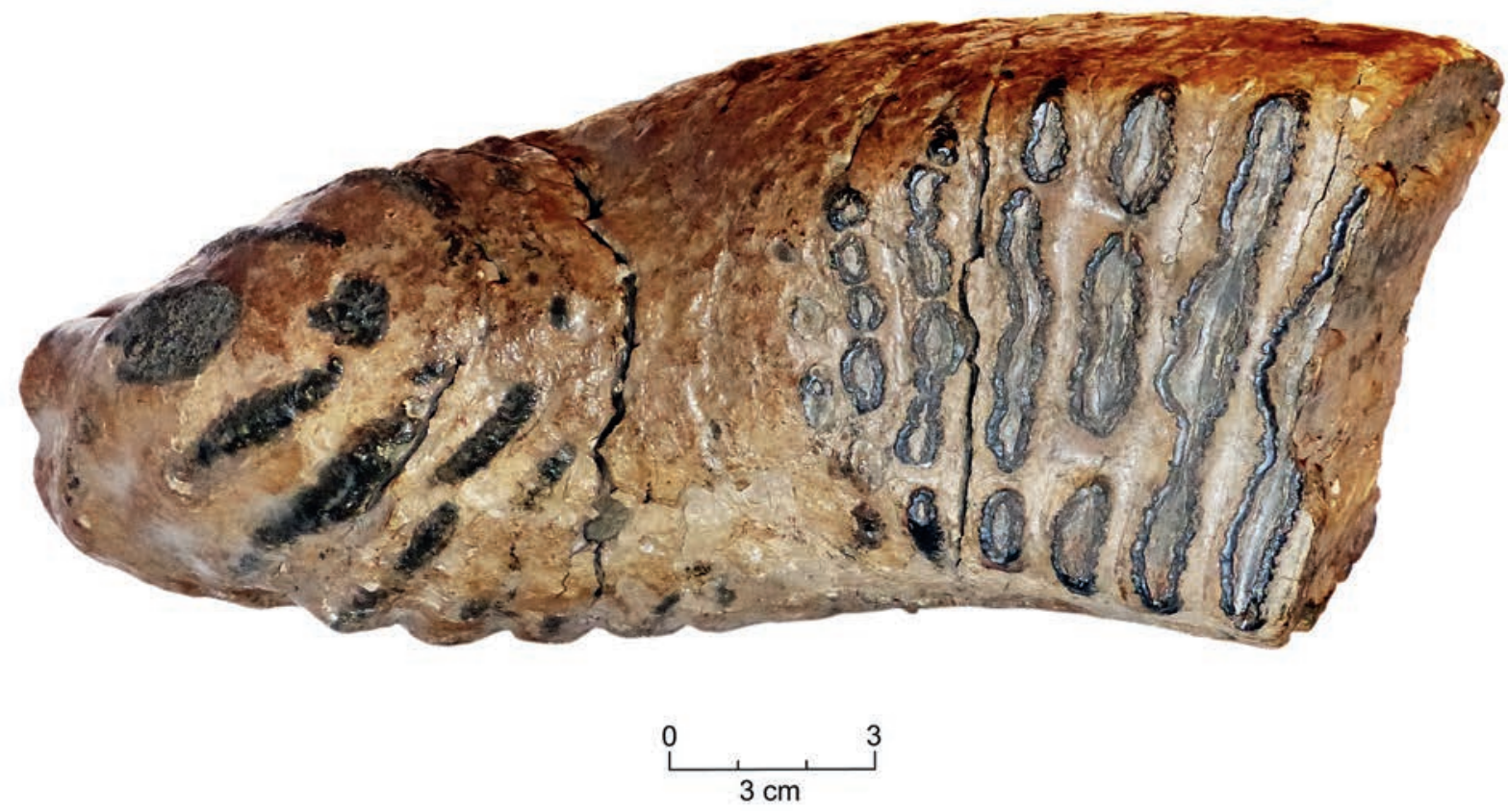

Fig. 7. Archidiskodon m. voigtstedtensis, Dietrich, 1958. Lower M3 dex (IGM 9271), upper units of Sagarlyk - lower part of Sergeevo Suite, Mokhovo Quarry.

Thüringen, Germany correspond to the center of the peak. Averaged values PL: $18.3 \mathrm{~mm}$ and E: $2.79 \mathrm{~mm}$ of the Siberian form also appear almost in the center of its clusterization. Parameters of the holotype A. $m$. cromerensis Mayet et al., 1923 (Fig. 2, Point 13) also match the same adaptive peak (its boundary isoline). This form was initially described on the basis of the material from Forest Bed, England and later in several localities of France. Other than that, A. m. jockgrimensis Dietrich, 1958 and A. m. vestinus Azzaroli, 1972 have been distinguished in this age interval in Western Europe (Gunz-Mindel and beginning of Mindel of Alpine Scale, final part of Early Pleistocene, Early Galerian of modern scales). The former is undistinguishable from $A$. m. voigtstedtensis, while the latter is closer to typical subspecies.

Turning back to our diagrams, it has to be concluded that the statistically distinct adaptive peak under consideration represents normal distribution of parameters in the limits of average values PF: 5.25 - 6; PL: $17.0-19.0 \mathrm{~mm}$ and E: $2.6-3.2 \mathrm{~mm}$.

Since holotypes $A . m$. voigtstedtensis and $A . m$. cromerensis (Fig. 2, points 14 and 13) correspond to this adaptive peak, it can be regarded as fully justified taxon, as it was presumed by the authors of the mentioned forms and demonstrated by the means of our method long ago (Foronova and Zudin 1986, 1999, etc.). Put another way, it has to be regarded as the most advanced and adapted form within species A. meridionalis typical of the transitional time between Early and Middle Pleistocene. Given that parameters of $A$. m. voigtstedtensis correspond to the center of its clusterization, we consider it reasonable to retain this particular name for this form.

Recently, the form from Voigtstedt was being mentioned in the papers of authors from Western Europe analyzing the findings from the localities of the beginning of the early Middle Pleistocene, namely West Runton (WR), UK (Lister and Stuart 2010). Describing a complete skeleton from West Runton the authors define it as Mammuthus trogontherii and tend to equal the locality with Voigtstedt. In the meantime, they suppose a model whereby M. meridionalis was still present in Europe at the beginning of the early Middle Pleistocene, along with M. trogontherii immigrating from the East, and hybrids between them (Lister and Sher 2001; Lister et al. 2005). According to this point of view, they consider molars from Voigstedt as meridionalis/trogontherii 'mosaic' (intermediate/mosaic at Voigtstedt) and point out that the WRM is more advanced than that 'mosaic' mammoths. 
It is our opinion that right and left M3 shown in Fig. 27 (Lister and Stuart 2010) have more archaic composition than $M$. trogontherii. Besides, if one considers attributing WR molars to $M$. trogontherii strictly, it is necessary to juxtapose its parameters to those of the lectotype of this form. In Fig. 2 these parameters (according to Dubrovo 1964) are marked by Point 11, but WR molars do not match to this distribution area. Averaged parameters of WR form: PF: 5.65, E: $2.5 \mathrm{~mm}$ calculated by us (according to Lister and Stuart 2010, tab. 5, p. 186) appear to be on the very boundary of the adaptive peak $A . m$. voigtstedtensis and station closer not to $M$. trogontheri, but to the form marked by Point 12 (which is to be discussed below).

Apparently, a variation of molars from Sinyaya Balka, Taman is also to be compared with A. m. voigtstedtensis. Authors of its description (Baygusheva and Titov 2012) regard it as belonging the second form, which taxonomic status requires further study (unfortunately, paper does not provide geological correlation and age indication). Bimodal distribution of some parameters in the Sinyaya Balka locality is associated with this form (Lister et al. 2005). According to the authors, "some trogontherioid characters are already evident at Taman' and other late Early Pleistocene European sites, so the pattern of change and replacement was evidently complex". In this regard it should be noticed that on our above mentioned calculations of average values of WR molars (PF: 5.65, E: $2.56 \mathrm{~mm}$ ) are close to average values of the group of molars from Sinyaya Balka (PF: 5.7, PL: $18.5 \mathrm{~mm}$, E: $2.6 \mathrm{~mm}$ ), from collection of MGPI, Moscow (our measurements).

Thus, numerous material - from Western and Eastern Europe and Siberia - testifies that mammoth lineage in this transitional time period (the very end of Early - beginning of Middle Pleistocene) was subject to considerable changes and adaptations to new changing environment of the Quaternary. This most important stage in the development of the group was crucial for the transformation of Archidiskodon to Mammuthus (Foronova and Zudin 1986, 1999, 2001).

\section{Archidiskodon aff. wüsti (M. Pavlowa, 1910)} (Figs. 2, 3)

Material. 2 Lower M3 sin (IGM 106, 3547), upper part of Sergeevo Suite, Novosergeevo Quarry. Upper M3 dex (IGM 5034), upper part of Sergeevo Suite, Mokhovo Quarry. Lower M3 (IGM 1), Kedrovka
Suite (Krasnogorsk beds), Novosergeevo Quarry. Lower M3 dex (IGM 6003), upper units of Sergeevo Suite or lower part of Kedrovka Suite, Mokhovo Quarry. Upper M3 sin (IGM 5847), paired lower M3 sin and dex (IGM 1990), upper part of Sergeevo Suite, Bachatsk Quarry.

Geological age. Final part of Early Pleistocene, Early Galerian/Cromerian.

Description, comparisons and remarks. Generally, the molars are large: length of lower: over $265.0 \mathrm{~mm}$, upper: $385.0 \mathrm{~mm}$; width: $102.0-106.0 \mathrm{~mm}$; height: $140.0 \mathrm{~mm}$; number of plates (incomplete): up to 20. Variations of values: PF: 5.2-5.6; PL: 17.0-19.0 mm; E: 1.9-2.4 mm. Averaged values PL: $18.5 \mathrm{~mm}$; E: $2.2 \mathrm{~mm}$.

In parameters of $\mathrm{PF}$ and $\mathrm{PL}$ this form is analogous to previously described $A$. m. voigtstedtensis, while its enamel thickness is considerably lower. Diagrams show that according to the provided parameters, this form is, so to say, 'on the junction' of the two genera Archidiskodon and Mammuthus, while it substantially differs from $M$. trogontherii by lesser PF and greater PL (Figs. 2, 3). Averaged values provided before show that these molars correspond to a peculiar, strictly isolated and large adaptive peak (Point 12). Stationed here are also the parameters of $A$. woüsti Pavlowa, 2010 (according to Alekseeva 1977); average values (PL: $18.3 \mathrm{~mm}$, E: $2.3 \mathrm{~mm}$, our measurements) of the most typical M3 from Kolkotova Balka, Moldova; as well as average parameters (PL: $18.0 \mathrm{~mm}, \mathrm{E}$ : $2.2 \mathrm{~mm}$, our measurements; Figs. 2, 3, Point 12) of the elephant's teeth described by Baygusheva and Garutt (1987) as Archidiskodon trogontherii (Pohlig 1885) from Azov, Rostov Region (the skeleton of the AMZ).

A. wüsti was established by M. Pavlowa (1910) on the basis of the archaic variation of $E$. (meridianalis) trogontherii Pohlig (1885) and teeth from Tiraspol (Moldova). Pohlig (1885) has noted that this species had had an intermediate position zoologically as well as geologically, i.e. had represented a sort of a 'bridge' between the southern elephant and the mammoth. Later, Dubrovo (1963b) considered it to be only a synonym of Pohlig's E. trogontherii and described its earlier variation as a nominative subspecies of $M$. trogontherii trogontherii within the genus Mammuthus (Dubrovo 1966). Taking into account everything written above, we consider that so-called 'earlier form' of trogontherii elephant is an independent form, and should be attributed to the 
genus Archidiskodon, as it was thought previously (Pohlig 1885; Pavlow 1910; Yatsko 1948; Sher 1971; Alekseeva 1977). Besides, a number of compelling arguments in favor of belonging of Azov Elephant to the genus Archidiskodon is provided in the paper of Baygusheva and Garutt (1987). Authors mentioned the structure of molars with meridionaloid attrition figure and, which is most remarkable, well-developed long chin projection that was typical of archidiskodon elephants, but not mammoths.

The European structure of the lineage (Fig. 2) allows us to consider the controversial question of the range of a wide species Elephas trogontherii Pohlig, 1885. Once again it has to be emphasized, that it is the abrupt decrease in enamel thickness, mentioned before, that qualifies the special position of this form in the lineage structure. Besides, other important dental characteristics emerged on this stage of its development. While the width of a crown in early forms changes gradually, slightly decreasing from the archaic to the later forms, the hypsodonty index increases 'leap-like' on the borders of the adaptive peak ensembles (Fig. 2). The first such leap coincides with the border (depression in the structure) between the ensembles with A. m. meridionalis (Points 18, 17), and A. m. tamanensis (Points 16,15). The next border (large depression) is remarkable for the biggest leap of the hypsodonty index in the lineage (Foronova and Zudin 1986, 1999). This fact may be indicative of its taxonomical status. The border separates the above mentioned forms and two distinct ensembles approximately in one plate frequency range, but differing in enamel thickness. The first one is in the thick-enamel area, with $A$. m. voigtstedtensis and the second one is in the thin-enamel area, with $A$. wüst $i$ (teeth from M. Pavlowa's collection (MGPI, Moscow) and A. trogontherii from Azov, described by Baygusheva and Garutt (1987)). Such changes in the teeth of the archidiskodons, undoubtedly adaptive in their nature, were accompanied by corresponding changes in cranial proportions (Osborn 1942; Garutt 1954; Azzaroli 1977, etc.). A distinct specialization by enamel thickness fixed in this part of the graph and an isolation of corresponding forms of late archidiskodons correspond with the global nature and climate fluctuations in the beginning of the Quaternary. No less significant statistically is the border between the above mentioned forms and the adaptive peak with the parameters of the lectotype M.t. trogontherii (Figs. 2, 3; point 11) from Süssenborn. The crown width and hypsodonty index almost does not change here. This border, however, is very important in terms of statistics, since it is this border that is marked by the wide spreading of the early representatives of the genus Mammuthus to the higher latitudes. This stage is associated with the problems still widely discussed, such as the border between the genera Archidiskodon and Mammuthus, and the intermediate and ancestral forms of the elephants of the mammoth group.

\section{CONCLUSIONS}

The question of early stages of mammoth fauna development is rather complicated and depends on many unknowns. In the present paper we approach one of the most complicated problems of evolution of Quaternary proboscides - to revealing of so called intermediate forms in the mammoth lineage and defining of their taxonomic status. Intermediate forms between major species of the genera Archidiskodon and Mammuthus (A. meridionalis - M. trogontherii $M$. primigenius) have long been known, but most of them require additional description and taxonomic identification. In the paper "On the history of discovery of intermediate links in the phylogenetic sequence of elephants Archidiskodon - Mammuthus" V.E. Garutt (1971) gave detailed overview of these forms and pointed out these problems. Nevertheless, a solution, which required dealing with wide variability and transgression of dental morphological features, was impossible without finding a new uniform statistical method for study of vast collected material. At that time under supervision of V.E. Garutt author started extensive examination of material (collections of ZIN, PIN, GIN and Garutt's data from many collections abroad) and development of the first statistical approach named 'method of optimal measurements' (Garutt and Foronova 1976). Later in 1980s it permitted to create a new multi-level method - cluster analysis of even larger ranges of M3. It resulted in creation of multidimensional diagrams for Europe and Siberia (Figs. 2, 3) that graphically demonstrate a model of the structure of Archidiskodon - Mammuthus in Northern Eurasia, as well as the whole course and main direction of its evolution on the basis of dental features (Foronova and Zudin 1986, 1999, 2001; Foronova 2001a, b, 2007, 2014a, b).

The material demonstrated in this paper and its position in the lineage structure indicate that meridionaloid elephants, beginning from $A$. meridionalis, 
existed in Western Siberia in Early Pleistocene since the beginning of Late Villafranchian. All their transitions (evolutional transformations) to the genus Mammuthus were also traced (Figs. 2, 3).

Analysis of the structure itself shows that lineage, so to say, 'searches its way' to adapt to new, more severe, environmental conditions of the 2 nd half of the Early Pleistocene, especially at the boundary between Early and Middle Pleistocene. This is reflected both on Siberian and European diagrams, especially on the latter (Fig. 2), which encompasses far more of the factual data. It shows a wide variability range of analyzed PL, FL, and E of ancient elephants in Europe. At that time, evolutional tendencies in the lineage have not established yet, but even then a steady trend can be seen towards increase of plate frequency (and decrease of average, 'front-rear' length). These two correlating features change rather gradually throughout all the development of the lineage, but at certain critical stages lineage 'leaps' towards thinner enamel, responding to environmental changes, and resumes its more or less gradual development on new adaptation level. In other words, enamel thickness was the most sensitive adaptation feature. In periods of smooth development of taxa (represented as adaptive peaks on the diagrams) variability within populations manifested itself in the range of normal distribution.

Thus, it can be supposed that the lineage structure reflects three consecutive stages of its development (on the basis of the features of FP, LP and E) (Fig. 2). First: within genus Archidiskodon, from the earliest meridionalis to A. m. voigtstedtensis; two others: throughout the existence of genus Mammuthus. One from A. wüsti (Point 12) to M. intermedius Jourd. and early form of M.primigenius (Points 8 and 6) (Foronova 2014b); and another from M. p. fraasi Dietr. (Point 4) to the latest M. primigenius (Point 1). These three stages were separated and caused by two 'leaps' in enamel thickness, which coincide with well-pronounced, statistically significant depressions in the distribution of material (though the very first small leap of enamel thickness is registered on the stage A. meridionalis - A. m. tamanensis (Points 16-15). We correlate these two significant depressions with taxonomical boundaries: 1) between genera Archidiskodon and Mammuthus, 2) within large ensemble of adaptive peaks (taxa) corresponding to genus Mammuthus. The first such event can be seen before a generic border (Points 14-12) at the stage of late archidiskodons, from $A . m$. voigtstedtensis to $A$. wüsti (1.0-0.8 Ma approx.). The second one is before a border between the early and late forms of M. primigenius (Points 6-4), at the stage of the 'early' one (0.16 Ma approx.). It is remarkable that it is these mammoths that are characterized by the maximum plate quantity in the lineage (30). It has to be noted that the most important feature, the hypsodonty index, increases 'leap-like' on the borders of the adaptive peak ensembles, regarded as taxonomical boundaries. It is important that these leaps correspond to two mentioned leaps of enamel thickness.

These boundaries are remarkable by their outstanding paleogeographical events, which probably caused two large waves of expansions: first to the middle latitudes of Eurasia, and then to the extremely high ones (Foronova and Zudin 1986, 1999, 2001; Foronova 2001b, 2007). As it was demonstrated in our paper, during the existence of the lineage, in the process of its evolution and adaptation to environmental changes during all the Quaternary, mostly the thin-enamel phenotype was repeatedly fixed on by selection. Thin-enamel forms could have been pioneers in settling new adaptive zones and advancing progressive development of the mammoth lineage at the transitions of Pleistocene major environmental changes towards cold and arid climates.

These evolutional processes underlain and determined a far more complex - discrete rather than gradualistic, as it was considered before - character of lineage development. This fact was established and demonstrated by us for the first time with the help of created method and informative diagrams (Foronova and Zudin 1986, 1999, 2001).

\section{ACKNOWLEDGEMENTS}

I express my deepest gratitude to my mentors, Dr. Vadim E. Garutt and Dr. Vera S. Baygusheva, AMZ, Azov, Rostov Region, who opened my way to paleontology and were generously sharing their knowledge and always lending support. I am greatly indebted to Dr. Alexander N. Zudin who greatly contributed to development of the method and was supportive of my research. I am grateful to Dr. Alexey S. Tesakov, GIN RAS, Moscow for cooperation and support; to Dr. Vadim V. Titov, SSC RAS, Rostov-onDon for comments that contributed to improvement of the manuscript and for making photographs. I am also thankful to Igor V. Foronov for continuous help in translation of my papers. 


\section{REFERENCES}

Alekseeva L.I. 1977. Theriofauna of the Early Antropogene of Eastern Europe. Nauka, Moscow, 214 p. [In Russian].

Alexeeva L.I. and Garutt V.E. 1965. New data on the evolution of the elephant genus Archidiskodon. Byulleten' Komissii po Izucheniyv Chetvertichnogo Perioda, 30: 161-166. [In Russian].

Azzaroli A. 1977. Evolutionary patterns of Villafranchian Elephants in central Italy. Atti della Academia nazionale dei Lincei Anno 374. Classe di Scienze Fisiche, Matematiche e Naturali, 13(14): 149-168.

Baygusheva V.S. 2000. New data on Taman Faunistic Complex from the excavation site near village Semibalki (Azov region). In: Kiyashko V.Ya. (Ed.). Historical and Archeological Researches in Azov and at Lower Don in 1998. Vol. 16. Azov: 27-57. [In Russian].

Baygusheva V.S. and Garutt V.E. 1987. The skeleton of the steppe elephant Archidiskodon trogontherii (Pohlig 1885) from the northeastern Azov region. Proceedings of the Zoological Institute, 168: 3-20. [In Russian].

Baygusheva V.S. and Titov V.V. 2008. The Taman faunal complex of large vertebrates of the Azov and Lower Don regions. International conference on Early Paleolithic of Eurasia: new discoveries. SSC Russian Academy of Sciences, Rostov-on-Don: 123-124.

Baygusheva V. and Titov V. 2010. The evolution of eastern European meridionaloid elephants. Quaternaire (Hors serie), 3: 13-16.

Baygusheva V. and Titov V. 2012. The evolution of Eastern European meridionaloid elephants' dental characteristics. Quaternary International, 255: 206-216.

Belyaeva E.I. 1925. Elephas trogontherii Pohl. from Taman Peninsula. Trudy Geologicheskogo i Mineralogicheskogo Muzeja AN SSSR, 5(1): 1-15. [In Russian].

Darlington F. 1966. Zoogeography. Geographical Distribution of Animals. Progress, Moscow, 518 p. [In Russian].

Dietrich W.O. 1958. Übergangsformen des Südelephanten (Elephas meridionalis Nesti) im Altpleistozän von Thüringen. Geologie, 7: 79-82.

Dubrovo I.A. 1963a. New data on the Tamanian faunal complex of vertebrates. Bulletin of Moscow Society of Naturalists. Geological Series, 38(6): 94-99. [In Russian].

Dubrovo I.A. 1963b. On systematic position of Elephas wüsti. Paleontologicheskiy Zhurnal, 4: 95-102. [In Russian].

Dubrovo I.A. 1964. Elephants of genus Archidiskodon on the territory of USSR. Paleontologicheskiy Zhurnal, 3: 82-94. [In Russian].

Dubrovo I.A. 1966. Systematic position of an elephant from the Khozar faunal assemblage. Byulleten' Komissii po Izucheniyv Chetvertichnogo Perioda, 32: 63-74. [In Russian].
Foronova I.V. 1982. New mammal finds in the Pleistocene sediments of the Kuznetsk Basin. Trudy Zoologicheskogo Instituta AN SSSR, 111: 50-57. [In Russian].

Foronova I.V. 1990. Quaternary mammals of the Kuznetsk Basin and their stratigraphical significance. Abstract of the Candidate of Geologo-Mineralogical Sciences thesis. Novosibirsk, 24 p. [In Russian].

Foronova I.V. 1999. Quaternary mammals and stratigraphy of the Kuznetsk Basin (Southwestern Siberia). Antropozoikum "Quaternary of Siberia”, 23: 71-98.

Foronova I.V. 2001a. History of Quaternary Proboscideans of the south of Western Siberia inferred from dental system analysis. In: G. Cavarretta, P. Gioia, M. Mussi and M.R. Palombo (Eds). The World of Elephants. Proceedings of the First International Congress, Roma. Consiglio Nazionale delle Ricerche, Roma: 109-114.

Foronova I.V. 2001b. Quaternary mammals of the southeast of Western Siberia (Kuznetsk Basin): phylogeny, biostratigraphy, and palaeoecology. Publishing House of Siberian Branch, Russian Academy of Sciences, GEO, Novosibirsk, 243 p. [In Russian, with English summary].

Foronova I.V. 2007. Thin-enamel dental specialization in mammoth evolution: an example of direction selection. Quaternary International, 169-170: 95-104.

Foronova I.V. 2014a. Mammoths of the Molodova V Paleolithic site (Dniester Basin): The case of dental thinenamel specialization and paleoecological adaptation. Quaternary International, 326-327: 235-242.

Foronova I.V. 2014b. Mammuthus intermedius (Proboscidea, Elephantidae) from the late Middle Pleistocene of the Southern Western and Central Siberia, Russia: problem of intermediate elements in the mammoth lineage. Russian Journal of Theriology, 13(2): 141-153.

Foronova I.V. and Zudin A.N. 1986. A new approach to the study of north Eurasian fossil elephants of the Archidiskodon-Mammuthus lineage. In: S.A. Arkhipov (Ed.). Biostratigraphy and Paleoclimates of the Pleistocene in Siberia. Nauka, Novosibirsk: 6-31. [In Russian].

Foronova I.V. and Zudin A.N. 1999. The structure of the lineage Archidiskodon-Mammuthus in Eurasia and peculiarities of its evolution. Deinsea, 9: 103-118.

Foronova I.V. and Zudin A.N. 2001. Discreteness of evolution and variability in mammoth lineage: method for group study. In: G. Cavarretta, P. Gioia, M. Mussi and M.R. Palombo (Eds). The World of Elephants. Proceedings of the First International Congress, Roma. Consiglio Nazionale delle Ricerche, Roma: 540-543.

Garutt V.E. 1954. Southern elephant Archidiskodon meridionalis (Nesti) from the Pliocene of the Northern Coast of Azov Sea. Trudy Po Izucheniyu Chetvertichnogo Perioda, 10(2): 1-76. [In Russian].

Garutt V.E. 1971. History of distinguishing of intermediate elements in the lineage Archidiskodon - Mam- 
muthus. In: V.A. Zubakov and V.V. Kocheruga (Eds). Chronology of the Glacial Age. Geographicheskoye obshchestvo SSSR, Leningrad: 78-88. [In Russian].

Garutt V.E. and Alexeeva L.I. 1964. New data on evolution of elephants of genus Archidiskodon. Abstracts of All-Union Meeting for Researching of Quaternary. Novosibirsk: 7-8. [In Russian].

Garutt V.E. and Bajgusheva V.S. 1981. Archidiskodon gromovi Garutt et Alexeeva - der älteste Elefant der Mammutlinie in Eurasien. Quartärpaläontologie, 4: 7-18.

Garutt V.E. and Foronova I.V. 1976. Research on the teeth of extant elephants: methodological recommendations. Institute for Geology and Geophysics, Novosibirsk, 36 p. [In Russian].

Lister A.M. and Sher A.V. 2001. The origin and evolution of the wooly mammoth. Science, 294: 1094-1097.

Lister A.M., Sher A.V., Van Essen H. and Wei G. 2005. The pattern and process of mammoth evolution in Eurasia. Quaternary International, 126-128: 49-64.

Lister A.M. and Stuart A.J. 2010. The West Runton mammoth (Mammuthus trogontherii) and its evolutionary significance. Quaternary International, 228: 180-209.

Maglio V.J. 1973. Origin and evolution of the Elephantidae. Transactions of the American Philosophical Society, 63(3): 1-149.

Mayet L., Roman F. and Depéret C. 1923. Les éléphants pliocènes. Annales de l'Université de Lyon, 43: 162.

Miller R. and Kan J. 1965. Statistical analysis in geology. Publishing House MIR, Moscow, 81 p. [In Russian].

Nesti F. 1825. Sulla nuova specie di elefante fossile del Valdarno. Nuovo Giornale Dei Letterati, 2(24): 195-216.

Nikolskiy P.A., Titov V.V., Tesakov A.S., Foronova I.V. and Baygusheva V.S. 2014. Early Biharian Archidiskodon meridionalis (Nesti, 1825) from Sarkel (Lower Don area, Southern European Russia) and associated small mammals. VI International conference on mammoths and their relatives. Abstract book. Thessaloniki: 142 .

Osborn H.F. 1942. Proboscidea. Vol. 2. American Museum Natural history Press, New York: 805-1676.

Pavlow M. 1910. Les elephants fossiles de la Russie. Nouveaux mémoires de la Société Imperiale Naturelle de Moscou, 17(2): 1-56.

Pohlig H. 1885. Ueber eine Hipparionen-Fauna von Maragha in Nordpersien. Zeitschrift der Deutschen geologischen Gesellschaft, 37: 1022-1027.

Sher A.V. 1971. Pleistocene mammals and stratigraphy of the Far Northeast of the USSA and North America. Nauka, Moscow, 310 p. [In Russian, with English summary].

Söergel W. 1912. Elephas trogontherii Pohl. und Elephas antiquus Falc., ihre Stammesgeschichte und ihre Be- dentung für die Gliederung des deutschen Diluvium. Palaentografia, 60: 1-114.

Tesakov A.S. 2004. Biostratigraphy of the Middle Pliocene - Eopleistocene of Eastern Europe (on the basis of small mammals). Nauka, Moscow, 247 p. [In Russian, with English summary].

Vangengeim E.A. and Zazhigin V.S. 1965. Some results of the study of Antropogene mammal fauna of Western Siberia. In: V.N. Saks (Ed.). Main Problems of the Quaternary. Nauka, Moscow: 301-311.

Vangengeim E.A. and Zazhigin V.S. 1972. Mammal fauna of Siberia. International colloquium on the border between Neogene and Quaternary system. Book of reports, 2: 263-277. [In Russian].

Vereshchagin N.K. 1957. Mammal remains from Lower Quaternary deposits of Taman Peninsula. Trudy Zoologicheskogo Instituta AN SSSR, 22: 9-49. [In Russian].

Vereshchagin N.K. 1959. Mammals of the Caucasus: the history of the fauna. Academy of Sciences of the USSR Institute of Zoology, Moscow, Leningrad, 763 p. [In Russian].

Vislobokova I.A. 1973. Paleontological foundation of Eopleistocene stratigraphy of the south of Western Siberia. Abstract of the Candidate of Geologo-Mineralogical Sciences thesis. Novosibirsk, 24 p. [In Russian].

Vislobokova I.A. 1974. On a new find of Archidiskodon gromovi Garutt et Alekseeva from the Eopleistocene deposits of the south West Siberia). Byulleten' Komissii po Izucheniyu Chetvertichnogo Perioda. 42: 171-176. [In Russian].

Vislobokova I.A. 1996. The Pliocene Podpusk-Lebyazh'e mammalian faunas and assemblage, Western Siberia. Paleontographia Italica, 83: 1-23.

Wüst E. 1901. Untersuchungen über das, Pliozän und das älteste Pleistozan Thüringens. Abhandlungen der Naturforschenden Gesellschaft zu Halle, 23: 17-352.

Yatsko I.Y. 1948. The skeleton of Elephas wüsti M. Pavl. from Terrace Drifts of Khadzhibey Liman near g. Odessa. Trudy Odesskogo Universiteta, 2: 54.

Zudin A.N., Votakh M.R., Galkina L.I. and Lipagina V.Ja. 1977. Stratigraphy of Pliocene - Quaternary beds of Pri-Ob Plateau. Transactions of Institute of Geology and Geophysics AN SSSR, 373: 1-100. [In Russian].

Zudin A.N., Nikolaev S.V., Galkina L.I., Butkeeva O.Yu., Ephimova L.J., Panychev V.A. and Ponomarjova E.A. 1982. Foundation of the stratigraphical scheme of the Neogene and Quaternary deposits in the Kuznetsk Basin. Transactions of Institute of Geology and Geophysics AN SSSR, 521: 133-149. [In Russian].

Submitted July 5, 2018; accepted September 2, 2018. 